\title{
Interaction Studies of Sialic Acids with Model Receptors Contribute to Nanomedical Therapies
}

\author{
Hans-Christian Siebert ${ }^{1}$, Ruiyan Zhang ${ }^{1,2}$, Axel Scheidig ${ }^{2}$, Thomas Eckert ${ }^{1,3}$, Hans Wienk ${ }^{4}$, Rolf Boelens ${ }^{4}$, Mehran Mahvash ${ }^{5}$, Athanasios K. \\ Petridis $^{6}$, Roland Schauer \\ ${ }^{1}$ RI-B-NT - Research Institute of Bioinformatics and Nanotechnology, Schauenburgerstrasse 116, 24118 Kiel, Germany \\ ${ }^{2}$ Zoologisches Institut - Strukturbiologie, Zentrum für Biochemie und Molekularbiologie, Christian-Albrechts-Universität Kiel, Am Botanischen Garten 1-9, 24118 \\ Kiel, Germany \\ ${ }^{3}$ Klinik für Geburtshilfe, Gynäkologie und Andrologie, Fachbereich Veterinärmedizin, Justus-Liebig-Universität Gießen, Frankfurter Str. 106, 35392 Gießen, Germany \\ ${ }^{4}$ Bijvoet Center for Biomolecular Research, NMR Spectroscopy, Utrecht University, Padualaan 8, $3584 \mathrm{CH}$ Utrecht, The Netherlands \\ ${ }^{5}$ Neurochirurgische Abteilung, Klinikum Merheim, Köln, Germany \\ ${ }^{6}$ Neurochirurgie, Klinikum Duisburg GmbH, Zu den Rehwiesen 9, 47055 Duisburg, Germany \\ ${ }^{7}$ Biochemisches Institut, Universität Kiel, Olshausenstrasse 40, 24098 Kiel, Germany
}

\begin{abstract}
Sialic acid supports nerve cell regeneration, differentiation and neuronal plasticity. Especially, polysialic acid (polySia) chains which are built up by $\alpha 2,8$-linked Neu5Ac Neu5Ac residues influence by their specific interactions with polySia receptors neuronal processes related to tumor spread and differentiation processes. With a combination of biophysical and biochemical methods including molecular modeling as described here it is possible to support cell biological experiments and in vivo studies on a nanoscale level. The submolecular analytical approaches which are directed to crucial functional groups focus on the potential therapeutic impact of sialic acids and in particular polySia. Such results are helpful for the development of new drugs which might have a high clinical relevance in respect to the therapy of various diseases correlated to neuronal regeneration, tumor spread and infections. It is not surprising that several diseases belonging to these different clinical fields (e.g. oncology, infection diseases, neuronal disorder) can be treated as indicated because sialic acids represent essential contact structures on numerous cell surfaces in dependence to their state of differentiation.
\end{abstract}

Keywords: Nanomedical therapies; Polysialic acid; Cell-cell interactions

\section{Introduction}

A deeper insight into the biological role of sialic acids particularly polysialic acid (polySia) is possible when we understand the complementarity between structure and function on a submolecular level using a strategic combination of biochemical and biophysical methods. Similarities between interactions with cell pathogens and cell surfaces, cell-cell interactions, neuro-oncological mechanisms and nerve cell regeneration processes are obvious since sialic acids and especially the a2,8-linked Neu5Ac residues which build up polySia chains (Scheme 1) are often involved in these molecular recognition processes. These characteristic recognition processes are strongly dependent on the organ, the cell type and the stage of differentiation [1-6]. For example, in the respiratory and reproductive systems polySia covalently conneted with NCAM is discussed to counteract the cytotoxic characteristics of extracellular histones, which are generated during inflammation $[7,8]$. In contrast, in the neuronal system the interaction of polySia with histone $\mathrm{H} 1$ seems to be important for regeneration processes [9]. Thereby, histone $\mathrm{H} 1$ directly binds to polySia at an extracellular position as shown for cultured cerebellar

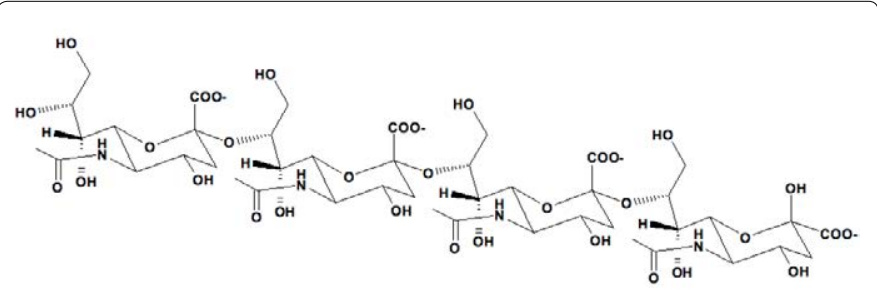

Scheme 1: Illustration of an $\alpha 2,8$-linked Neu5Ac tetramer. neurons. Immunostaining of living cerebellar neurons and Schwann cells confirmed that an extracellular pool of histone $\mathrm{H} 1$ colocalizes with polySia at the cell surface. Histone $\mathrm{H} 1$ stimulated neuritogenesis in vitro, process formation and proliferation of Schwann cells as well as migration of neural precursor cells via polySia-dependent mechanisms, further indicating that histone $\mathrm{H} 1$ is active extracellularly. These in vitro observations suggested an important functional role for the interaction between histone $\mathrm{H} 1$ and polySia not only for nervous system development but also for regeneration in the adult organism. Indeed, histone H1 improved glycan chain chafunctional recovery, axon regrowth, and precision of reinnervation of the motor branch in adult mice with femoral nerve injury [9]. Due to their important role in nervous system regeneration and neuro-oncological processes, polySia receptors (e.g. lectins) are of highest clinical importance [1012]. The involvement of sialic acid in general and polySia in special as well as sulfated oligosaccharides (e.g. the HNK-1 epitope) in neurite outgrowth allows to develop new therapeutic strategies with strong supportive impact on nervous system regeneration in mammals [13-17]. The neural cell adhesion molecule NCAM as well as other polySia-carrying proteins, i.e. neuropilin and the synaptic cell adhesion molecule SynCAM1, interact with these receptors via the polySia

*Corresponding author: Athanasios K. Petridis, Neurochirurgie, Klinikum Duisburg $\mathrm{GmbH}$, Zu den Rehwiesen 9,47055 Duisburg, Germany,, Tel: 004915123465406; E-mail: opticdisc@aol.com

Received February 05, 2015; Accepted February 26, 2015; Published February 28, 2015

Citation: Siebert HC, Zhang R, Scheidig A, Eckert T, Wienk H, et al. (2015) Interaction Studies of Sialic Acids with Model Receptors Contribute to Nanomedical Therapies. J Neurol Disord 3: 212. doi:10.4172/2329-6895.1000212

Copyright: (C) 2015 Siebert HC, et al. This is an open-access article distributed under the terms of the Creative Commons Attribution License, which permits unrestricted use, distribution, and reproduction in any medium, provided the original author and source are credited. 
Citation: Siebert HC, Zhang R, Scheidig A, Eckert T, Wienk H, et al. (2015) Interaction Studies of Sialic Acids with Model Receptors Contribute to Nanomedical Therapies. J Neurol Disord 3: 212. doi:10.4172/2329-6895.1000212

\begin{tabular}{|l|l|l|l|l|l|l|l|l|l|l|l|l|l|l|l|l|l|l|l|l|l|l|l|}
\hline SHL-1 conf. & 1 & 2 & 3 & 4 & 5 & 6 & 7 & 8 & 9 & 10 & 11 & 12 & 13 & 14 & 15 & 16 & 17 & 18 & 19 & 20 \\
\hline Trp32 & No & No & Yes & Yes & Yes & No & Yes & Yes & No & Yes & No & No & No & Yes & No & Yes & Yes & No & No & No \\
\hline
\end{tabular}

Table 1: Three Trp residues are stabilizing in the SHL-1 - sialic acid complex: Trp23, Trp25 and in parts Trp32. Twenty energy minimum conformations based on the NMR conformations of the ligand-free SHL-1 structure 1QK7.pdb (59) are listed. A contribution of Trp32 in the initial part of complex formation has been detected in nearly half of the analyzed conformations. Nine-times "Yes" means participation in the sialic acid recognition process in respect to Trp32. Eleven-times "No" indicates a lack of involvement concerning Trp32 when the initial binding step with the carbohydrate-recognition region of SHL-1 is discussed.

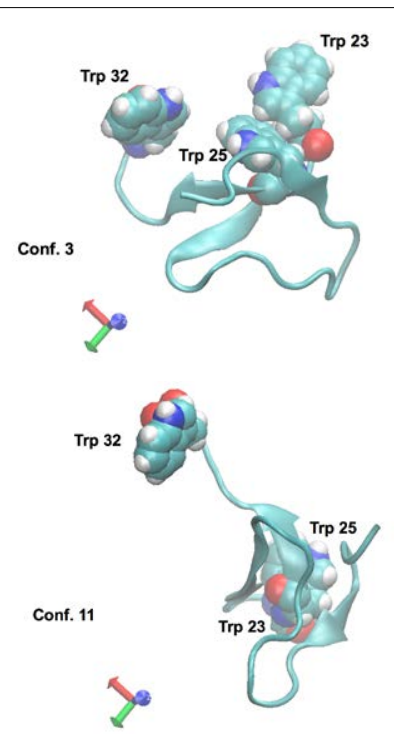

Figure 1: Conformation 3 (top) and conformation 11 (bottom) of the lectin SHL-1 from the Chinese bird-hunting spider Selenocosmia huwena Wang (Wang $=$ King) are listed in Table 1. Three tryptophane residues (Trp23, Trp25, Trp32) are involved in ligand binding (18) and highlighted in a van-der-Waals presentation. The conformations 3 (top) and 11 (bottom) correspond to a ligand-free NMR structure of SHL-1 (59). In contrast to Trp23 and Trp25, which are essential for ligand binding, the Trp32 residue stabilizes the complex, but is not crucial for the initial specific ligand recognition step.
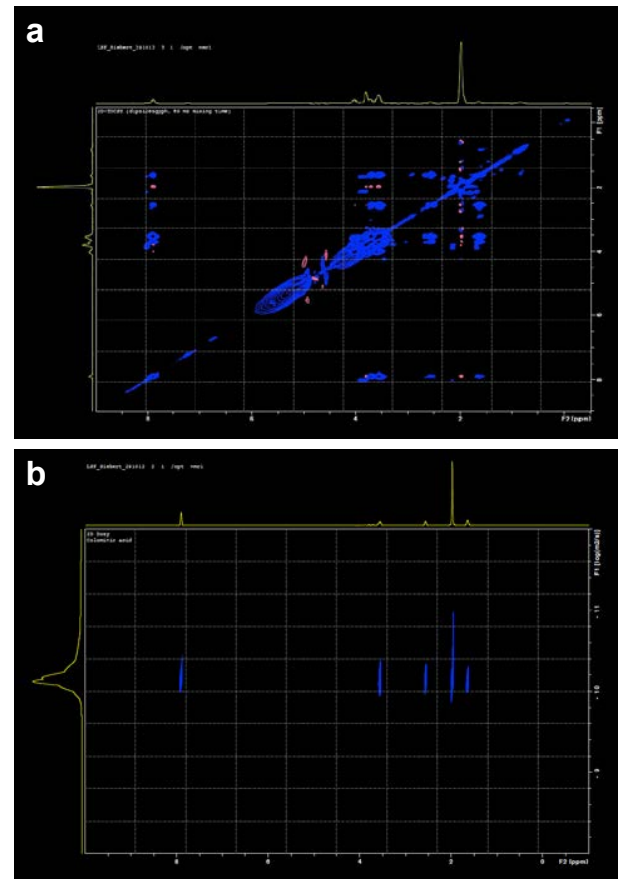

Figure 2: (a) TOCSY NMR spectrum of colominic acid ( $\alpha 2,8$-linked Neu5Ac polysaccharide chains of different size). (b) DOSY (Diffusion Ordered SpectroscopY) NMR spectrum of colominic acid which can be used to determine the size distribution of the $\alpha 2,8$-linked Neu5Ac polysaccharide fragments. glycan chain. The building block of the polySia glycan chain is the disaccharide repeating unit $\alpha 2,8$-linked sialic acid which interacts with the amino acid residues highlighted in Figure 1. In order to analyze the intermolecular processes between sialic acid molecules and their receptors on a nanoscale level suited model systems are needed. Such a suited model system is provided by the lectin SHL-1 from the Chinese bird hunting spider Selenocosmia huwena Wang. Sialic acid receptors of different origin have structural similarities in the architecture of their carbohydrate recognition domains (CRDs), pertaining, for instance, in the three-dimensional arrangement of crucial residues [18,19]. Beside arginine residues, aromatic amino acids, such as tryptophan and tyrosine (Figure 1) are often involved in sialic acid interaction processes [18-21]. However, as indicated by the different conformational states listed in Table 1 the structural dynamics of a sialic acid receptor is of highest relevance for the carbohydrate recognition process.

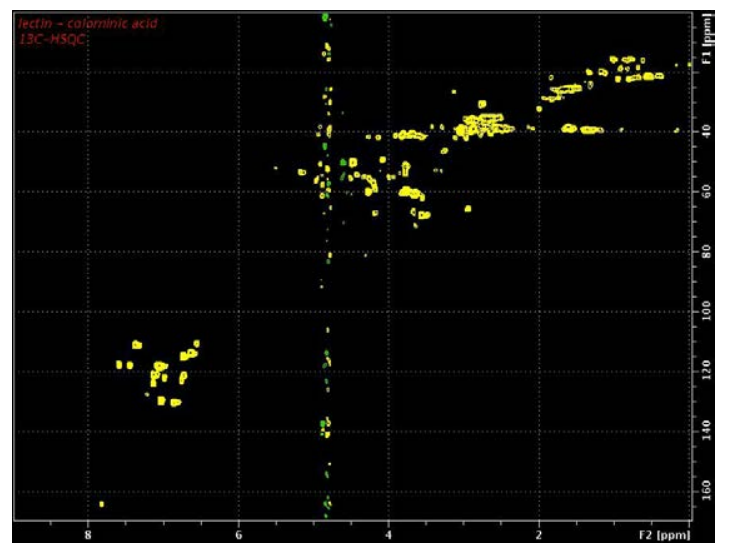

Figure 3: ${ }^{13} \mathrm{C} \mathrm{HSQC} \mathrm{(Heteronuclear} \mathrm{Single} \mathrm{Quantum} \mathrm{Coherence)} \mathrm{NMR} \mathrm{spectrum}$ of the lectin SHL-1from the Chinese bird-hunting spider Selenocosmia huwena Wang in the presence of colominic acid.

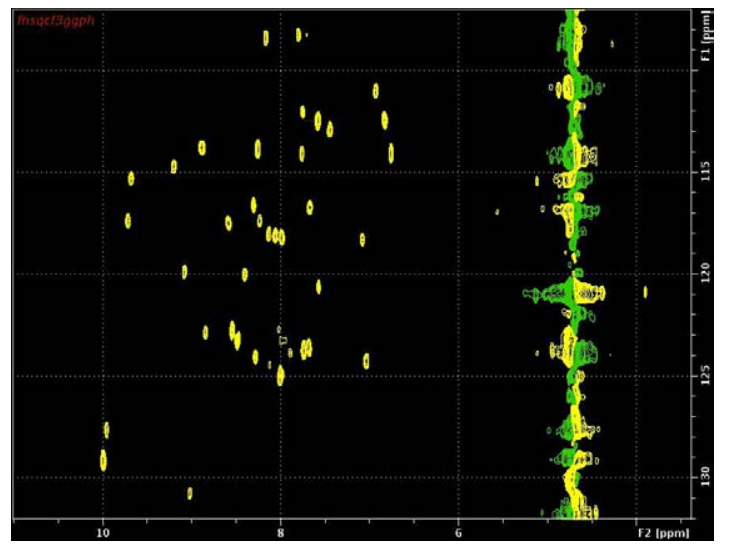

Figure 4: ${ }^{15} \mathrm{~N}$ HSQC (Heteronuclear Single Quantum Coherence) NMR spectrum of the lectin SHL-1from the Chinese bird-hunting spider Selenocosmia huwena Wang in the presence of colominic acid. 
Citation: Siebert HC, Zhang R, Scheidig A, Eckert T, Wienk H, et al. (2015) Interaction Studies of Sialic Acids with Model Receptors Contribute to Nanomedical Therapies. J Neurol Disord 3: 212. doi:10.4172/2329-6895.1000212

\section{Results and Discussion}

\section{Analytical approaches}

To further validate these nanomedical role models, it is advisable, for instance, to make use of nuclear magnetic resonance (NMR) methods which monitor the interactions between polySia and its sialic acid receptors (Figures 2-4). NMR and molecular modeling studies can be further extended to define whether the ligand-binding results are in agreement with general binding principles and/or similarities in the CRD architectures of sialic acid receptors [18-21]. In this context the strategic combination of methods lead to a new nanomedical approach in neurosciences providing data that explain why bio-active molecules like cyclic and linear peptides or small organic molecules can act as glycomimetics [22-34]. Especially, polar molecules with partially equalized single and double bonds which can be analyzed with ab initio calculations are proper candidates for effective new drugs which can mimick sialic acid functions. O-acetylated sialic acids are suited blueprints to identify further glycomimetic molecules since $\mathrm{O}$-acetylation at various positions on Neu5NAc represents an important functional group [35]. In this context we have also refined our tools to understand the molecular interactions on a nanoscale level, thereby, we considered beside polySia the binding processes of HNK-1 and related sulfated saccharides. Furthermore, bio-active peptides and small organic molecules show specific interactions with receptors such as laminin, myristoylated alanine-rich C kinase substrate (MARCKS) and various integrins. Processes of neuronal regeneration and tumor growth are related to sialic acid concentrations as we have learned from stem cell studies. Therefore, it is feasible to invent new therapeutic strategies in these important field of neurological disorders with panels of suited molecules. The physiological role of polySia shall now be discussed in order to understand how inhibition of its expression or increasing of its expression can affect cancer growth as well as central nervous system cell regeneration.
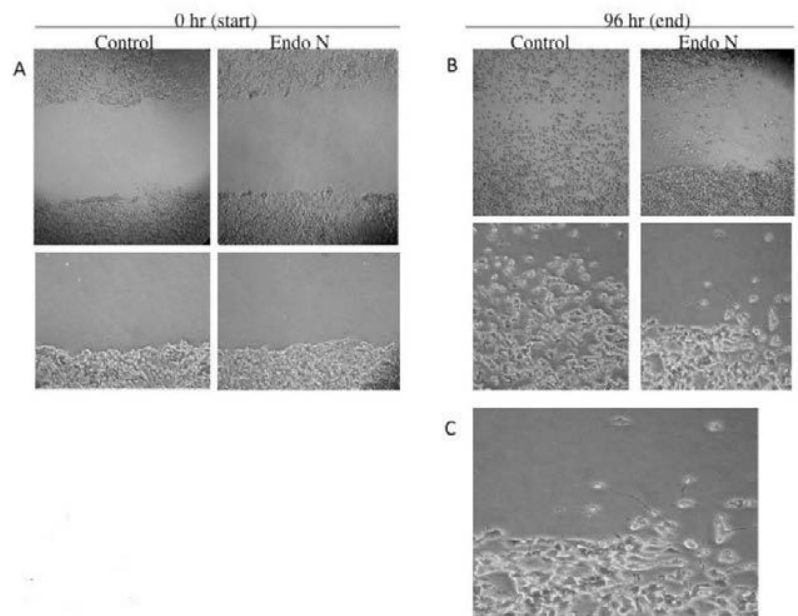

Figure 5: PolySia cleavage inhibits neuroblastoma cell migration. Wound scratch assay of neuroblastoma cell culture. A. Starting point $(0 \mathrm{hr})$. In controls the cells (SY5Y neuroblastoma, which are polySia rich) were untreated and in the endo $\mathrm{N}$ group, enodneuraminidase $(3 \mathrm{U} / \mathrm{ml}$ ) was added into the culture medium. B. 96 hours after treatment the migration into the wound scratch in the endo $\mathrm{N}$ treated cultures was significantly reduced and in addition the cells started to build clusters (cell-cell interactions seem to be enabled). After endoneuraminidase $\mathrm{N}$ treatment neuroblastoma cells showed to establish an axonal growth, which can be seen in the magnified image in $\mathrm{C}$.

\section{Therapeutical and diagnostic consequences}

PolySia cleavage and tumor cell differentiation are directly related to each other. A number of studies have shown that polySia is overexpressed in malignant tumors like malignant gliomas, small cell lung cancer, neuroblastomas to name a few [12,36-43]. It has been postulated that polySia enables tumor cells to keep an undifferentiated state and therefore to exist outside of the cellular "social network" and grow irrespective of regulating factors expressed by their neighbor cells. Also the characteristic polySia function, to accelerate migration of stem cells [44-46], is used by tumor cells to infiltrate normal tissue and metastasize [12]. As a logical consequence, polySia seems to act as NCAM interaction inhibitor. This means that different pathways induced by NCAM activation can be blocked by the expression of polySia on NCAM. The presence of polySia on NCAM inhibits this interaction [47] and keeps tumor cells away from differentiation back to normal cells. In relation to this it is of clinical interest that the transcription factor Pax3 involved in tumorigenesis seems to induce NCAM polysialylation on medulloblastoma cells [48]. Regarding these processes on a nanoscale level, polySia inhibits cell-cell interactions through its ability to bind significant amount of water and therefore

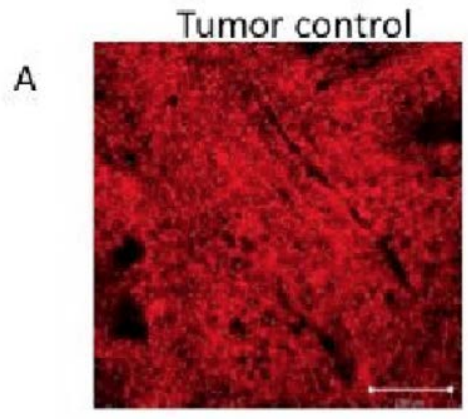

Endo $\mathrm{N}$ activation in Serum $5 \mathrm{~min}, 3 \mathrm{hr}$ and $6 \mathrm{hr}$ after i.v. injection of $500 \mathrm{U}$ end

B

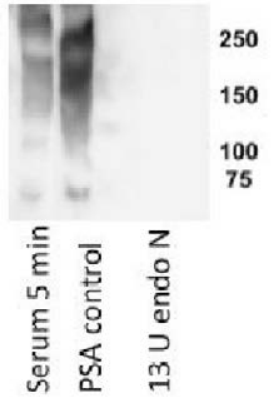

Figure 6: A: PolySia immunostainings expression in rhabdomyosarcoma cells. PolySia immunostainings of a rhabdomyosarcoma tumor induced into a Bulb C mouse. B: When endoneuraminidase $N$ is applied intrathecally in animals, polySia in the subventricular zone stem cells is cleaved. However when endoneuraminidase $\mathrm{N}$ is applied intravenously to animals, polySia is not cleaved from tumor cells. It could be shown that the presence of serum inactivates endoneuraminidase N. When Serum was added in a cell culture and the polySia rich cells (SY5Y neuroblastoma cells) were treated with endoneuraminidase $\mathrm{N}$ the enzyme was inactive and failed to remove polySia from the cells. Serum 5 min: SY $5 Y$ cells treated with endo $\mathrm{N}$ for $5 \mathrm{~min}$ in the presence of serum. PolySia is present as a smear from 150-250 kDa. PolySia-control: SY5Y cultures not treated with endo N. $13 \mathrm{U}$ endo N:SY5Y cells treated with endo $\mathrm{N}$ without the presence of Serum. No polySia can be seen. Western blot electrophoresis of SY5Y cell lysates stained with anti-polySia antibody 5 A5. 
Citation: Siebert HC, Zhang R, Scheidig A, Eckert T, Wienk H, et al. (2015) Interaction Studies of Sialic Acids with Model Receptors Contribute to Nanomedical Therapies. J Neurol Disord 3: 212. doi:10.4172/2329-6895.1000212

Page 4 of 6

keeping receptors away from their ligand or other receptors. Some studies are postulating that polySia expression of tumor cells can be used as a prognostic factor in different tumors. Wilms tumor patients with increased polySia expression for example have a shorter survival time, therefore, polySia was claimed to be an oncodevelopmental antigen $[49,50]$.

\section{Nanomedical improvements}

Apart from using polySia as a prognostic marker in tumors there is also a therapeutic approach to tumors through cleavage of polySia from the surface of polySia expressing tumor cells.

Endoneuraminidase $\mathrm{N}$ is a polySia selective cleavage enzyme. A polySia cleavage in neuroblastoma cells with the non-toxic endoneuraminidase $\mathrm{N}$ induces differentiation of these cells with developing axons and expressing neurofilaments [38]. Additionally, the migration capacity of these cells was significantly reduced [38,51-53] (Figure 5). Unfortunatelly, in vivo experiments with intravenous application of endoneuraminidase $\mathrm{N}$ in animals with polySia-rich tumors failed to remove polySia from the tumor cells. Reason of this seemed to be factors in the serum, which inactivated endoneuraminidase $\mathrm{N}$ there (Figure 6). Therefore, different alternative delivery methods for endoneuramoinidase to tumors have to be evaluated. Since the cleavage of polySia from tumor cells is a promising tool in the treatment of cancer nanomedical tools for their delivery are now under construction. These tools can also be used as vessels for polySia fragments and other molecules with an impact on neuronal differentiation. It is important to mention that polySia is not oncogenic. This molecule is expressed by tumor cells but there are no observations that it is inducing cancer. It is indeed fascinating that new drugs can be developed by a precise knowledge of the structural and functional properties of polySia, HNK-1 and the corresponding glycomimetic molecules. The high clinical relevance in respect to the therapy of diseases correlated to neuronal regeneration, tumor spread and infection opens a wide field for medical and pharmacological research projects. It should not be surprising that various diseases of different origin can be treated with drugs based on polySia because this

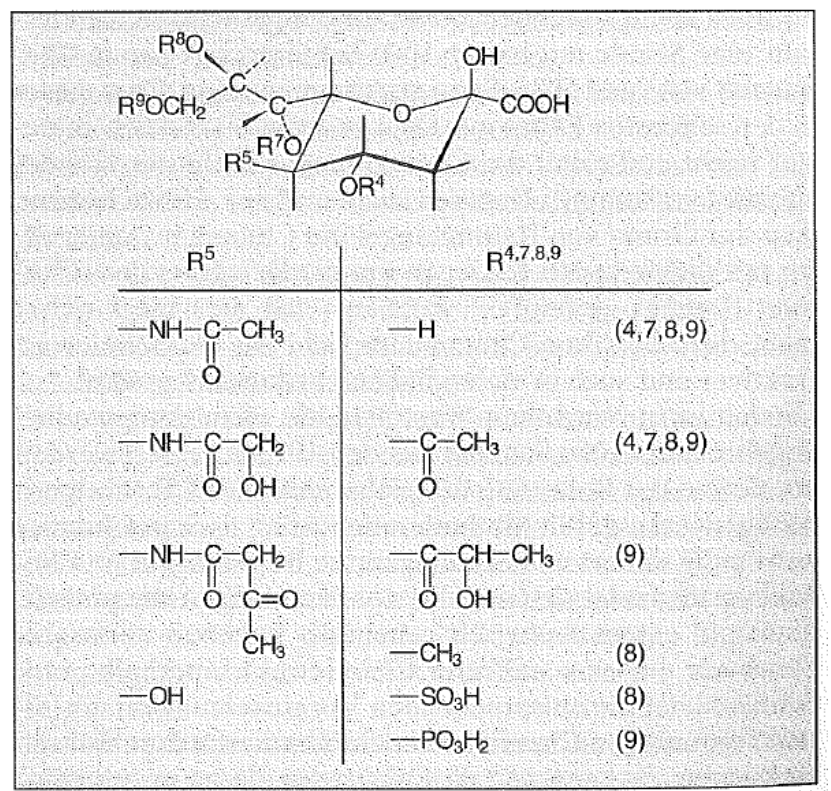

Figure 7: The carboxyl group $(\mathrm{COOH})$. The $\mathrm{N}$-acetyl group (left column) is always found at $\mathrm{C}$-atom 5 whereas an $\mathrm{O}$-acetyl group (right column) can be attached to the $\mathrm{C}$-atoms $4,7,8$ and 9 of a sialic acid residue.

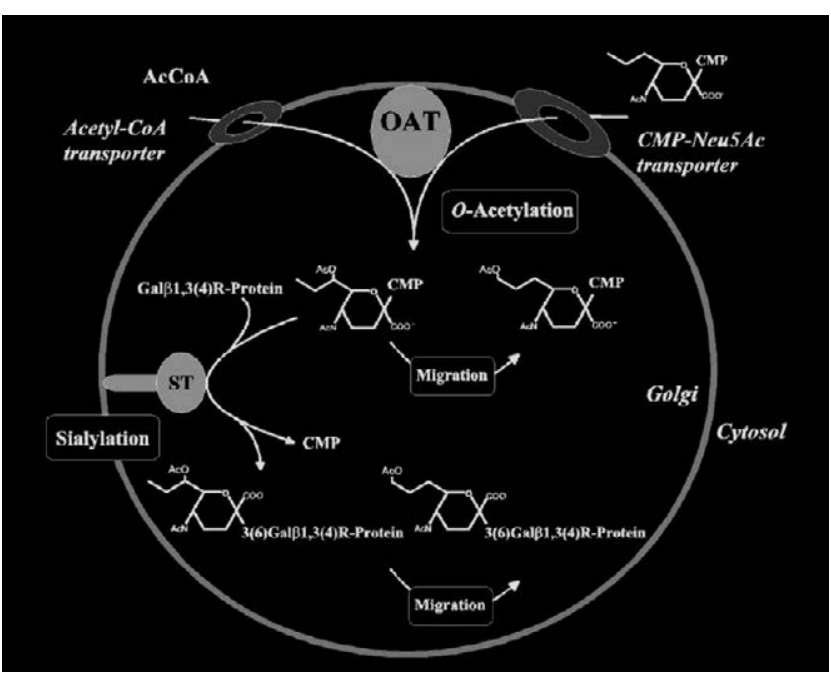

Figure 8: The postulated pathway for the incorporation of O-acetyl groups into sialic acids in human colon mucosa. ST, sialyltransferase; R, GICNAc or GalNAc. The migration (or isomerisation) of acetyl groups from C-7 to C-9, as shown in the postulated pathway, can occur spontaneously under mildalkaline conditions, or as postulated by Vandamme-Feldhaus and Schauer 1998 (54), be catalyzed by a hypothetical 'migrase'. It is unclear whether isomerisation takes place at the nucleotide-sugar level or following sialic acid transfer to glycoprotein acceptors. a
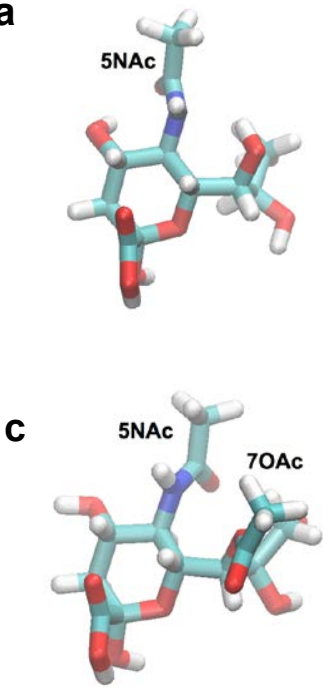

b
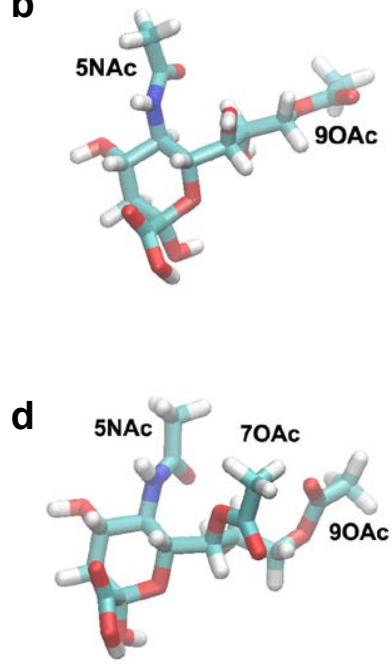

Figure 9: Quantum chemical calculations of (a) NeuN5Ac, (b) Neu5NAc9OAc, (c) Neu5NAc7OAc, (d) Neu5NAc7,90Ac were carried out with the DFT (Density Functional Theory) method (B3LYP/6-31G*) using the Gaussian03 program. Beside the 5-acetyl group also 90-acetyl- and 70-acetyl groups are important contact parts for the fine-tuning of ligand - receptor interactions when sialic acids are involved.

polysaccharide has to be considered as an essential contact structure on the cell surface related to many innovative clinical approaches in the field of nanomedicine. In particular, O-acetylation of sialic acids may play an important role in respect to a rational-based design of new drugs since the $\mathrm{O}$-acetyl groups act as special recognition points (Figure 7). The postulated pathway for the incorporation of O-acetyl groups into sialic acids in human colon mucosa is described in the literature $[54,55]$ and shown in (Figure 8 ). When the biological effects of sialic acid modifications caused by different functional groups have to 
Citation: Siebert HC, Zhang R, Scheidig A, Eckert T, Wienk H, et al. (2015) Interaction Studies of Sialic Acids with Model Receptors Contribute to Nanomedical Therapies. J Neurol Disord 3: 212. doi:10.4172/2329-6895.1000212

be understood completely it is essential to consider all their biophysical properties. As it is the case when studying olfaction processes beside the molecular shape and its dynamics also the vibrational states of certain functional groups have to be considered [56]. Quantum chemical calculations of (a) Neu5Ac, (b) Neu5Ac9OAc, (c) Neu5Ac7OAc, (d) Neu5Ac7,9OAc were carried out with the DFT (Density Functional Theory) method (B3LYP/6-31G*) using the Gaussian03 program in order to collect all these physical parameters. Pictures of the energy minimum conformations are displayed in (Figure 9) This knowledge opens new routes for a rational based drug design of molecules, since also the complete set of physical parameters including the vibrational states of these molecules are taken into account. In such a context therapeutical improvements could be expected in relation to sialic acid - receptor interactions especially when focusing on polySia with special patterns of $\mathrm{O}$-acetyations. A combination of the biophysical methods described here with clinical studies could lead to neuro-oncological approaches related to applied patient-care $[57,58]$.

\section{Acknowledgement}

We thank Philipp Siebert for technical assistance and Prof. Dr. Hubertus Maximilian Mehdorn (Department of Neurosurgery, Universitatsklinikum SchleswigHolstein Campus Kiel, Kiel, Germany) for fruitful scientific discussions. Elements of the project are financed by the European Commission's Framework Program 7 (Bio-NMR; project number 261863)

\section{References}

1. Schauer $R$ (2009) Sialic acids as regulators of molecular and cellular interactions. Curr Opin Struct Biol 19: 507-514.

2. Battistel MD, Shangold M, Trinh L, Shiloach J, Freedberg DI (2012) Evidence for helical structure in a tetramer of alpha2-8 sialic acid: unveiling a structural antigen. J Am Chem Soc 134: 10717-10720.

3. Sato C, Kitajima K (2013) Impact of structural aberrancy of polysialic acid and its synthetic enzyme ST8SIA2 in schizophrenia. Frontiers in cellular neuroscience $7: 61$.

4. Rollenhagen M, Kuckuck S, Ulm C, Hartmann M, Galuska SP, et al. (2012) Polysialylation of the synaptic cell adhesion molecule 1 (SynCAM 1) depends exclusively on the polysialyltransferase ST8Siall in vivo. J Biol Chem 287: 35170-35180.

5. Hildebrandt H, Dityatev A (2013) Polysialic acid in brain development and synaptic plasticity. Topics in current chemistry. Advance online publication.

6. Tiralongo J, Martinez-Duncker I (2013) Sialobiology: Structure, Biosynthesis and Function (eds J. T \& I. M-D, Betham e Books).

7. Simon P, Bäumner S, Busch O, Röhrich R, Kaese M, et al. (2013) Polysialic acid is present in nammalian semen as a post-translational modification of the neural cell adhesion molecule NCAM and the polysialyltransferase ST8Siall. J Biol Chem 288: 18825-18833.

8. Ulm C, Saffarzadeh M, Mahavadi P, Muiller S, Prem G, et al. (2013) Soluble polysialylated NCAM: a novel player of the innate immune system in the lung. Cell Mol Life Sci 70: 3695-3708.

9. Mishra B, von der Ohe M, Schulze C, Bian S, Makhina T, et al. (2010) Functional role of the interaction between polysialic acid and extracellular histone $\mathrm{H} 1$. J Neurosci 30: 12400-12413.

10. Rutishauser $U$ (2008) Polysialic acid in the plasticity of the developing and adult vertebrate nervous system. Nat Rev Neurosci 9: 26-35.

11. Senkov O, Sun M, Weinhold B, Gerardy-Schahn R, Schachner M, et al (2006) Polysialylated neural cell adhesion molecule is involved in induction of long-term potentiation and memory acquisition and consolidation in a fearconditioning paradigm. J Neurosci 26: 10888- 109898.

12. Petridis AK, Wedderkopp H, Hugo HH, Maximilian Mehdorn H (2009) Polysialic acid overexpression in malignant astrocytomas. Acta neurochirurgica 151: 601603; discussion 603-604

13. Siebert HC, Born K, André S, Frank M, Kaltner H, et al. (2006) Carbohydrate chain of ganglioside GM1 as a ligand: identification of the binding strategies of three 15 mer peptides and their divergence from the binding modes of growth-regulatory galectin-1 and cholera toxin. Chemistry - A European Journal 12: 388-402.
14. Kleene R, Schachner M (2004) Glycans and neural cell interactions. Nat Rev Neurosci 5: 195- 208.

15. Masand SN, Chen J, Perron IJ, Hammerling BC, Loers G, et al. (2012) The effect of glycomimetic functionalized collagen on peripheral nerve repair Biomaterials 33: 8353-8362.

16. Mehanna A, Mishra B, Kurschat N, Schulze C, Bian S, et al. (2009) Polysialic acid glycomimetics promote myelination and functional recovery after peripheral nerve injury in mice. Brain 132: 1449-1462.

17. Schauer R (2004) Sialic acids: fascinating sugars in higher animals and man Zoology (Jena) 107: 49-64

18. Siebert HC, Lü SY, Wechselberger R, Born K, Eckert T, et al. (2009) A lectin from the Chinese bird-hunting spider binds sialic acids. Carbohydr Res 344 1515-1525.

19. Siebert HC, Lư SY, Frank M, Kramer J, Wechselberger R, et al. (2002) Analysis of protein-carbohydrate interaction at the lower size limit of the protein part (15mer peptide) by NMR spectroscopy, electrospray ionization mass spectrometry, and molecular modeling. Biochemistry 41: 9707-9717.

20. Siebert HC, André S, Lu SY, Frank M, Kaltner H, et al. (2003) Unique conformer selection of human growth-regulatory lectin galectin-1 for ganglioside GM1 versus bacterial toxins. Biochemistry 42:14762-14773.

21. André S, Kaltner $H$, Lensch M, Russwurm R, Siebert HC, et al. (2005) Determination of structural and functional overlap/divergence of five proto-type galectins by analysis of the growth-regulatory interaction with ganglioside GM1 in silico and in vitro on human neuroblastoma cells. Int J Cancer 114: 46-57.

22. Bhunia A, Vivekanandan S, Eckert T, Burg-Roderfeld M, Wechselberger R, et al. (2010) Why structurally different cyclic peptides can be glycomimetics of the HNK-1 carbohydrate antigen. J Am Chem Soc 132: 96-105.

23. Tsvetkov YE, Burg-Roderfeld M, Loers G, Ardá A, Sukhova EV, et al. (2012) Synthesis and molecular recognition studies of the HNK-1 trisaccharide and related oligosaccharides. The specificity of monoclonal anti-HNK-1 antibodies as assessed by surface plasmon resonance and STD NMR. J Am Chem Soc 134: 426-435.

24. Siebert HC, Burg-Roderfeld M, Eckert T, Stötzel S, Kirch U, et al. (2010) Interaction of the alpha2A domain of integrin with small collagen fragments. Protein and Cell 1: 393-405.

25. Stötzel S, Schurink M, Wienk H, Siebler U, Burg-Roderfeld M, et al. (2012) Molecular organization of various collagen fragments as revealed by atomic force microscopy and diffusionordered NMR spectroscopy. ChemPhysChem a European journal of chemical physics and physical chemistry 13: 3117-3125.

26. Schadow S, Siebert HC, Lochnit G, Kordelle J, Rickert M, et al. (2013) Collagen metabolism of human osteoarthritic articular cartilage as modulated by bovine collagen hydrolysates. PLoS One 8: e53955.

27. Siebert HC, Rosen J, Seyrek K, Kaltner H, André S, et al. (2006) alpha2,3/ alpha2,6-Sialylation of $\mathrm{N}$-glycans: non-synonymous signals with marked developmental regulation in bovine reproductive tracts. Biochimie 88: 399-410.

28. Siebert HC, Tajkhorshid E, Dabrowski J (2001) Barrier to rotation around the Csp2-Csp2 bond of the ketoaldehyde enol ether $\mathrm{MeC}(\mathrm{O}) \mathrm{CH}=\mathrm{CH}-\mathrm{OEt}$ as determined by $13 \mathrm{C}$ NMR and ab initio calculations. J Phys Chem A: 8488-8494.

29. Lenthe JH, van Boer DHW, den Havenith RWA, Schauer R, Siebert HC (2004) $\mathrm{Ab}$ initio calculations on various sialic acids provide valuable information about sialic acid-specific enzymes. J. Mol. Struct. (THEOCHEM) 677: 29-37.

30. Eckert T, Stötzel S, Burg-Roderfeld M, Sewing J, Lutteke T, et al. (2012) In silico study on sulfated and non-sulfated carbohydrate chains from proteoglycans in Cnidaria and interaction with collagen. O J Phys Chem 2:123-133.

31. Krylov VB, Grachev AA, Ustyuzhanina NE, Ushakova NA, Preobrazhenskaya $\mathrm{ME}$, et al. (2011) Preliminary structural characterization, anti-inflammatory and anticoagulant activities of chondroitin sulfates from marine fish cartilage. Russian Chem Bull (Med Chem Issue) Int Ed 60: 746-753.

32. Siebert S, Engelhard P, Kraan S, Schauer R, Siebert HC (2013) Gibt es die Apotheke aus dem Meer? Praxis der Naturwissenschaften. Praxis der Naturwissenschaften - Biologie 2 (63): 39-42.

33. Raabe O, Reich C, Wenisch S, Hild A, Burg-Roderfeld M, et al. (2010) Hydrolyzed fish collagen induced chondrogenic differentiation of equine adipose tissue-derived stromal cells. Histochemistry and cell biology 134: 545-554 
Citation: Siebert HC, Zhang R, Scheidig A, Eckert T, Wienk H, et al. (2015) Interaction Studies of Sialic Acids with Model Receptors Contribute to Nanomedical Therapies. J Neurol Disord 3: 212. doi:10.4172/2329-6895.1000212

34. Jiménez-Barbero J, Javier Cañada $\mathrm{F}$, Asensio $\mathrm{JL}$, Aboitiz $\mathrm{N}$, Vidal $\mathrm{P}$, et al. (2006) Hevein domains: an attractive model to study carbohydrateprotein interactions at atomic resolution. Advances in carbohydrate chemistry and biochemistry 60: 303- 354 .

35. Siebert HC, von der Lieth CW, Dong X, Reuter G, Schauer R, et al. (1996) Molecular dynamics-derived conformation and intramolecular interaction analysis of the Nacetyl-9-O-acetylneuraminic acid-containing ganglioside GDla and NMR-based analysis of its binding to a human polyclonal immunoglobulin $\mathrm{G}$ fraction with selectivity for O-acetylated sialic acids. Glycobiology 6 (6): 561-572.

36. Seifert A, Glanz D, Glaubitz N, Horstkorte R, Bork K (2012) Polysialylation of the neural cell adhesion molecule: Interfering with poly-sialylation and migration in neuroblastoma cells. Arch Bioch Biophys 524: 56-63.

37. Petridis AK (2013) Implication of polysialic acid overexpression on tumorigenesis of neuroectodermal and other tumors. Impairment of cell adhesion. Recent Advances in Adhesion Research Nova Publishers: 115-122.

38. Petridis AK, El Maarouf A, Rutishauser U (2004) Polysialic acid regulates cell contactdependent neuronal differentiation of progenitor cells from the subventricular zone. Develop Dyn 230: 675-684

39. Miyahara R, Tanaka F, Nakagawa T, Matsuoka K, Isii K, et al. (2001) Expression of neural cell adhesion molecules (polysialylated form of neural cell adhesion molecule and L1-cell adhesion molecule) on resected small cell lung cancer specimens: in relation to proliferation state. J Surg Oncol 77: 49-54.

40. Gluer S, Schelp C, Gerardy-Schahn R, von Schweinitz D (1998) Polysialylated neural cell adhesion molecule as a marker for differential diagnosis in pediatric tumors. J Pediatr Surg 33: 1516-1520.

41. Glüer S, Schelp C, Madry N, von Schweinitz D, Eckhardt M, et al. (1998) Serum polysialylated neural cell adhesion molecule in childhood neuroblastoma. British J of Cancer 78: 106-110.

42. Suzuki M, Suzuki M, Nakayama J, Suzuki A, Angata K, et al. (2005) Polysialic acid facilitates tumor invasion by glioma cells. Glycobiology 15: 887-894.

43. Amoureux MC, Coulibaly B, Chinot O, Loundou A, Metellus P, et al. (2010) Poly sialic acid neural cell adhesion molecule (PSA-NCAM) is an adverse prognosis factor in glioblastoma, and regulates olig2 expression in glioma cell lines. BMC Cancer, 10: 91, 1-12.

44. Cremer H, Lange R, Christoph A, Plomann M, Vopper G, et al. (1994) Inactivation of the NCAM gene in mice results in size reduction of the olfactory bulb and deficits in spatial learning. Nature 367: 455-459.

45. Ono K, Tomasiewicz H, Magnuson T, Rutishauser U (1994) NCAM mutation inhibits tangential neuronal migartion and is phenocopied by enzymatic removal of polysialic acid. Neuron 13: 595-609.
46. Tomasiewicz H, Ono K, Yee D, Thompson C, Goridis C, et al. (1993) Genetic deletion of a neural cell adhesion molecule variant (NCAM-180) produces distinct defects in the central nervous system. Neuron 11: 1163-1174.

47. Petridis AK, Nikolopoulos SN, El-Maarouf A (2011). Physical and functional cooperation of neural cell adhesion molecule and beta1-integrin in neurite outgrowth induction. J Clin Neurosci 18: 1109-1113.

48. Mayanil CSK, George D, Mania-Farnell B, Bremer CL, McLone D, et al. (2000) Overexpression of murine Pax3 increases NCAM polysialylation in a human medulloblastoma cell line. J Biol Chem 275: 23259-23266.

49. Tanaka F, Otake Y, Nakagawa T, Kawano Y, Miyahara R, et al. (2001) Prognostic significance of polysialic acid expression in resected non-small cel lung cancer. Cancer Research 61: 1666-1670.

50. Roth J, Zuber C, Wagner P, Taatjes DJ, Weisgerber C, et al. (1988) Presence of long chain form of polysialic acid oft he neural adhesion molecule in Wilm's tumor. Am J Pathol 133: 227-239.

51. Seidenfaden R, Krauter A, Schertzinger F, Gerardy-Schahn R, Hildebrand $\mathrm{H}$ (2003) Polysialic acid directs tumor cell growth by controlling heterophilic neural cell adhesion molecule interactions. Mol Cell Biol 23: 5908-5918.

52. El Maarouf A, Petridis AK, Rutishauser U (2003) Use of polysialic acid in repair of the central nervous system. Proc Natl Acad Sci USA 103: 16989-94.

53. Cajal SG (1928). Degeneration and regeneration of the nervous system, vol. 1 and 2. Oxford University Press, London.

54. Vandamme-Feldhaus V, Schauer R (1998) Characterization of the enzymatic 7-O-acetylation of sialic acids and evidence for enzymatic O-acetyl migration from C-7 to C-9 in bovine submandibular gland. J Biochem (Tokyo) 124: 111-121.

55. Shen Y, Tiralongoa J, Kohla G, Roland Schauer R (2004) Regulation of sialic acid Oacetylation in human colon mucosa. Biol. Chem. 385: 145-152.

56. Franco MI, Turin L, Mershin A, Skoulakis EMC (2011) Molecular vibrationsensing component in Drosophila melanogaster olfaction. Proc Natl Acad Sci USA 108 (9): 3797-3802.

57. Mahvash M, Pechlivanis I, Charalampaki P, Jansen O, Mehdorn HM (2014) Visualization of small veins with susceptibility-weighted imaging for stereotactic trajectory planning in deep brain stimulation. Clinical Neurology and Neurosurgery 124: 151-155.

58. Fuster MM, Esko JD (2005) The sweet and sour of cancer: glycans as nove therapeutic targets. Nature Reviews Cancer 5: 526-542. 